\title{
EFFICIENCY AND QUALITY
}

\author{
UDC 666.1 .031
}

\section{TOPICAL PROBLEMS OF GLASSMAKING}

\section{Ya. Dzyuzer ${ }^{1}$}

Translated from Steklo i Keramika, No. 5, pp. 3 - 5, May, 2013.

\begin{abstract}
The problems limiting the process and economic efficiencies of glassmaking are examined. It is shown that high-capacity glassmaking furnaces which are also economically efficient are needed and can be designed and built.
\end{abstract}

Key words: glassmaking furnace, specific capacity, energy efficiency

In our opinion, Russia's entry into the WTO could exacerbate crises in the domestic glass industry. One can imagine that the state of this industry will be determined mainly by the dynamics of the development of two interrelated processes.

The first process is adverse and fully predictable — glass products become uncompetitive. This is due to a systemic increase in the cost of fuel-energy and materials resources as well as high specific consumption. As a result, in the near future, the payback time of the investment in glassmaking furnaces should exceed the operating time of the furnace and main process equipment between overhauls.

The second process is in essence positive. It anticipates a radical reassessment of the process efficiency for glass production. In practice, it is a question of formulating a modern concept for building a glass business based on world economic trends. This concept must be based on a fundamental principle used by leading foreign glass companies: a new production plant can be built or an existing plant rebuilt only on the basis of the highest process efficiency attained in world practice. Such an approach will make it possible to survive a crisis in the industry and preserve the industry as an integral part of the national economy.

To concretize we shall analyze the present status and examine the prospects for developing the main (melting) stage of the technological process of container glass production.

The overwhelming majority of the glass plants in the industry are equipped with modern competitive process equipment. The effectiveness of this equipment largely depends on the skills of the maintenance personnel and to a lesser extent

1 First President of Russia B. N. El'tsin Ural Federal University, Ekaterinburg, Russia (e-mail: vdzuzer@yandex.ru). on the quality of the design. At the same time the operating parameters of a glass furnace are determined mainly by the engineering standard of the design. Naturally, plant specialists must be trained in order to maintain this level. But even the best trained personnel cannot correct design and implementation errors.

In world practice, a complex of interrelated parameters is used to evaluate the technical effectiveness of glassmaking furnaces: capacity $C_{\mathrm{f}}$, tons/day; specific heat consumption per $1 \mathrm{~kg}$ glass produced $q_{\mathrm{sp}}, \mathrm{kJ} / \mathrm{kg}$; specific output of molten glass $C_{\mathrm{sp}}$, tons $/\left(\mathrm{m}^{2} \cdot\right.$ day $)$; and, total glass production per $1 \mathrm{~m}^{2}$ of the melting tank area over a furnace run $C_{\mathrm{sp}}^{\Sigma}$, tons $/ \mathrm{m}^{2}$ [1]. At the same time the parameters $C_{\mathrm{sp}}^{\Sigma}$ and $q_{\mathrm{sp}}$ are sufficient to determine the economic efficiency of the furnace. The first parameter is determined by the expression

$$
C_{\mathrm{sp}}^{\Sigma}=\frac{C_{\mathrm{f}}}{F_{\mathrm{mt}}} \mathrm{R}=C_{\mathrm{sp}} \mathrm{R}
$$

where $F_{\mathrm{f}}$ is the area of the melting tank, $\mathrm{m}^{2}$, and $\mathrm{R}$ is the furnace run, days.

The total output of molten glass per $1 \mathrm{~m}^{2}$ of the tank surface is the most important initial parameter for calculating the ROI. The quantity $C_{\mathrm{sp}}^{\Sigma}$ objectively characterizes the design standard, including its conformance to current notions about glassmaking efficiency.

The data in Fig. 1 graphically illustrate the evolution of glassmaking furnaces. In foreign practice the values $C_{\mathrm{sp}}^{\Sigma}=$ $4000-6000$ tons $/ \mathrm{m}^{2}$ were reached in the $1980 \mathrm{~s}$. This production level was reached with average specific molten glass production $2-2.5$ tons $/\left(\mathrm{m}^{2} \cdot\right.$ day $)$ and furnace run $4-6 \mathrm{yr}$. 


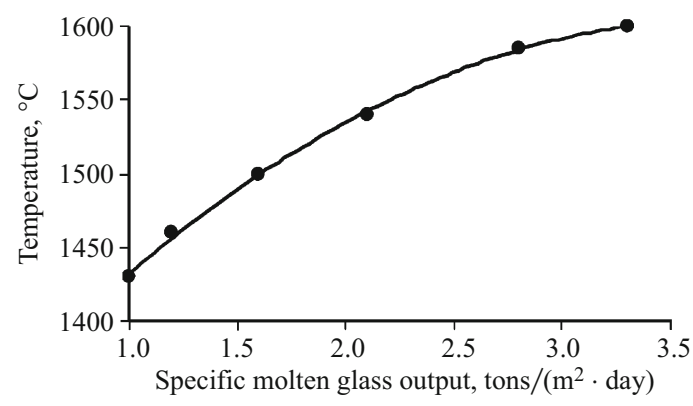

Fig. 1. Effect of the specific output on the molten glass production per $1 \mathrm{~m}^{2}$ of the melting tank area over a furnace run.

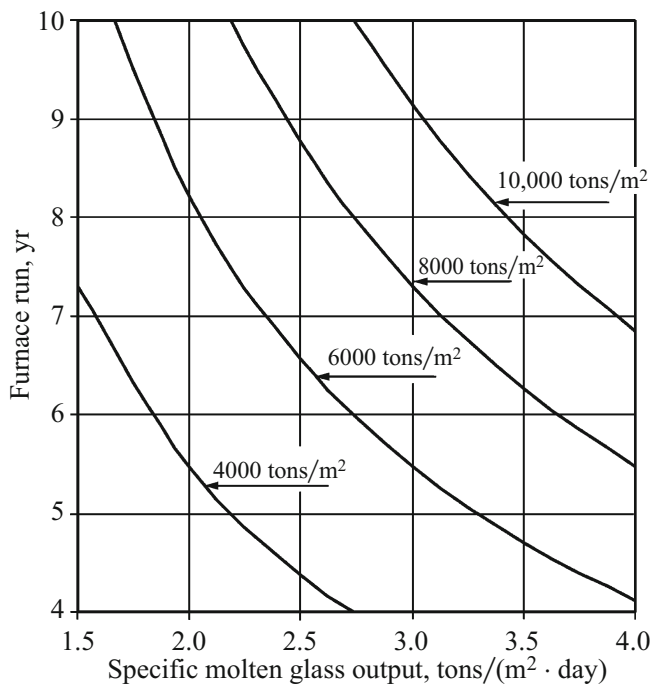

Fig. 2. Change in melting temperature with increasing specific molten glass output.

The new total production level $C_{\mathrm{sp}}^{\Sigma}=6000-8000$ tons $/ \mathrm{m}^{2}$ was reached in the 1990s. It became possible with $C_{\mathrm{sp}}=$ $2.5-3$ tons $/\left(\mathrm{m}^{2} \cdot\right.$ day $)$ and $\mathrm{R}=6-8 \mathrm{yr}$. It should be noted that the level $C_{\mathrm{sp}}^{\Sigma}=6000-8000$ tons $/ \mathrm{m}^{2}$ characterizes the average level of foreign glassmaking. For modern furnace $C_{\mathrm{sp}}^{\Sigma}=8000-10,000$ tons $/ \mathrm{m}^{2}$, which is reached with $C_{\mathrm{sp}} \geq 3$ tons $/\left(\mathrm{m}^{2} \cdot\right.$ day $)$ and $\mathrm{R}=8-10$ yr. For domestic container glass furnaces the average total production is $C_{\mathrm{sp}}^{\Sigma}=$ $3000-4000$ tons $/ \mathrm{m}^{2}$. The low value of $C_{\mathrm{sp}}^{\Sigma}$ for domestic furnaces is due to short furnace runs ( $5 \mathrm{yr}$ on average) and low specific molten glass output - about 2 tons $/\left(\mathrm{m}^{2}\right.$ - day).

For comparable current construction costs for furnaces the glass production per $1 \mathrm{~m}^{2}$ of melting tank over a run for domestic furnaces is approximately $1 / 2$ the average foreign production level. Only a very limited number of domestic furnaces operate more efficiently. Specifically, for the operating glassmaking furnaces at the Orekhovo-Zuevo Glass Company, JSC (OZSK, JSC) $C_{\mathrm{sp}}^{\Sigma}$ approaches 6000 tons $/ \mathrm{m}^{2}$.

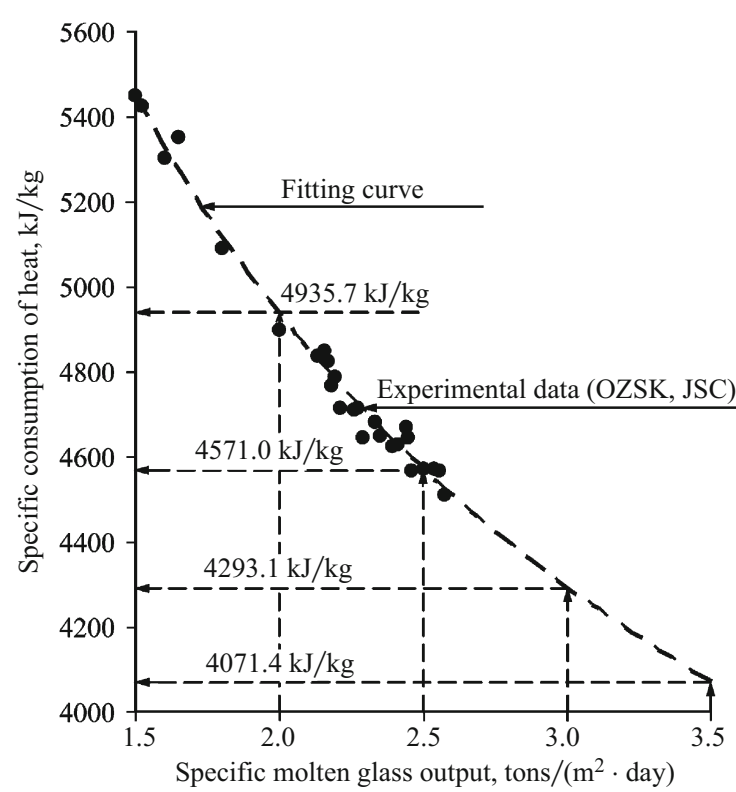

Fig. 3. Specific heat consumption for glassmaking versus the specific output of molten glass.

The data presented allow us to conclude that in order to reach a competitive glassmaking efficiency level the specific output of molten glass must be increased to $2.5-$ 3 tons $/\left(\mathrm{m}^{2} \cdot\right.$ day $)$ and the furnace run to $8 \mathrm{yr}$. The results of a Garstang analysis of the statistical data (Fig. 2) used in [1] shows that this level for $C_{\mathrm{sp}}$ is reached at melting temperatures $1569-1592^{\circ} \mathrm{C}$. These parameters correspond to the long-time working conditions of modern refractory and heat-insulation materials.

In summary, the problem of reaching the level $C_{\mathrm{sp}}^{\Sigma}=$ 8000 tons $/ \mathrm{m}^{2}$ is technically quite solvable. It can be solved on the basis of the existing experience in designing high-capacity glassmaking furnaces $[2,3]$.

We shall now proceed to the problem of the energy efficiency of glassmaking, which is evaluated by the specific heat consumption

$$
q_{\mathrm{sp}}=\frac{B Q_{\mathrm{n}}^{\mathrm{r}}+Q_{\mathrm{e}}}{C_{\mathrm{f}}}
$$

where $B$ is the fuel consumption, $\mathrm{m}^{3} / \mathrm{sec}$, and $Q_{\mathrm{e}}$ is the electric heating power (for a flame furnace $Q_{\mathrm{e}}=0$ ), $\mathrm{kW}$.

Experience shows that the problem of the energy efficiency of glassmaking can be solved only with a comprehensive approach to perfecting the design of glassmaking furnaces [4]. For modern container glass furnaces the energy efficiency attained is characterized by $q_{\mathrm{sp}}$ not exceeding $4.5 \mathrm{MJ} / \mathrm{kg}$. It is reached by using an energy-efficient design for the furnace enclosures [5] and increasing the specific output of molten glass to $2.5-3$ tons $/\left(\mathrm{m}^{2}\right.$. day $)$. The character of the dependence of $q_{\mathrm{sp}}$ on $C_{\mathrm{sp}}$ (Fig. 3) is explained by the fact that as the specific output of molten glass decreases the 


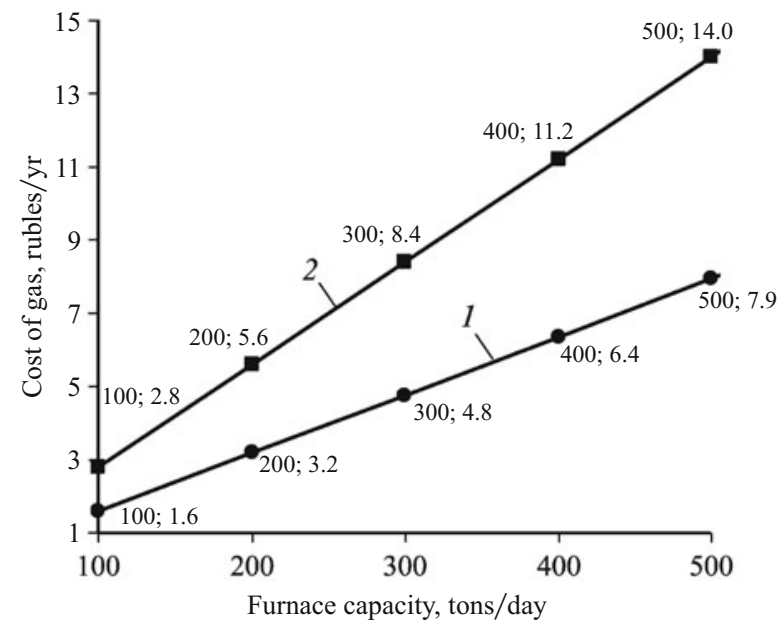

Fig. 4. Fuel cost savings with specific molten glass output increasing from 2 to $2.5(1)$ and 3 tons $/\left(\mathrm{m}^{2}\right.$. day) (2).

total area of the furnace enclosures decreases and, in consequence, so do the heat losses into the ambient medium.

Figure 3 shows the actual results of the operation of furnaces at the OZSK, JSC. By constructing fits to these results it is possible to predict the specific heat consumption for higher values of the specific output of molten glass. In addition, the heat conservation with increasing specific furnace capacity can be determined. The dependences presented in Fig. 4 were obtained for $1000 \mathrm{~m}^{3}$ of natural gas at a price of 4000 rubles. For the unavoidable convergence of domestic and foreign prices of fuel the financial losses with the operation of inefficient glassmaking furnaces will be tens of millions of rubles.

The dominant role of the specific output of molten glass in the economics of glass production also appears in the effect of this parameter on the cost of furnace construction.
The fact that for objective reasons the Russian glass industry is focused on foreign producers of refractory and heat-insulating articles has increased investment costs significantly. Actually, the same materials are used to construct efficient and inefficient furnaces. The ROI depends directly on the total production of molten glass per $1 \mathrm{~m}^{2}$ of the melting tank and the specific heat consumption for melting glass.

In summary, the development of objective prerequisites for making the domestic glass industry more competitive is inextricably tied to radical improvements in glass furnace design. The realization of this problem is limited by not technical factors but rather the mentality of the producers of glass products. Changing this mentality is the main condition for successful development of the industry.

\section{REFERENCES}

1. V. Ya. Dzyuzer, "Perfecting the technical characteristics of glassmaking furnaces," Steklo Keram., No. 7, 3-12 (2008); V. Ya. Dzyuzer, "Perfecting the technical characteristics of glassmaking furnaces," Glass Ceram., 65(9-10), 296-300 (2008).

2. V. Ya. Dzyuzer and V. S. Shvydkii, Construction of Energy-Efficient Glassmaking Furnaces [in Russian], Teplotekhnik, Moscow (2009).

3. V. Ya. Dzyuzer, V. S. Shvydkii, and E. B. Sadykov, "Modeling of the thermal operation of a high-capacity glassmaking furnace," Steklo Keram., No. 9, 23 - 27 (2012); V. Ya. Dzyuzer, V. S. Shvydkii, and E. B. Sadykov, "Modeling of the thermal operation of a high-capacity glassmaking furnace," Glass Ceram., 69(9-10), $302-305$ (2013).

4. V. Ya. Dzyuzer, "Methods for increasing the energy-efficiency of glass furnaces," Steklo Keram., No. 1, $11-14$ (2012); V. Ya. Dzyuzer, "Methods for increasing the energy-efficiency of glass furnaces," Glass Ceram., 69(1 - 2), 12 - 15 (2012).

5. V. Ya. Dzyuzer, "Energy-efficient furnace enclosures of high-capacity glassmaking furnaces," Ogneup. Tekh. Keram., No. 7 -8, $48-54$ (2009). 